\title{
Opportunities for the promotion of employability skills among the tribal women in Telangana state
}

Penumala, Vijaya Kumar $₫$

Research Scholar, Department of Commerce, Osmania University, Hyderabad, India (vijaykumarpenumala645@gmail.com)

Malyadri, P.

Principal, Government Degree College, Srisailam Project, Kurnool District, India (drpm16@gmail.com)

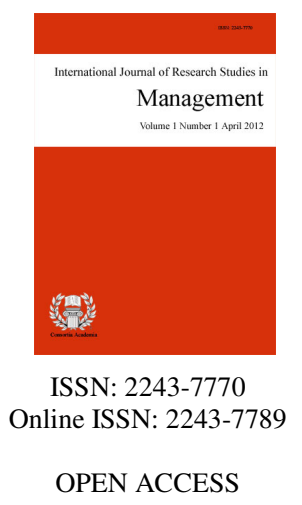

Received: 10 April 2017

Revised: 4 May 2017 DOI: $10.5861 /$ ijrsm.2017.1799

\section{Abstract}

The Telangana State Government is strongly focused on empowerment of tribal women especially in terms of creating the employment opportunities. Telangana State Scheduled Tribes Co-operative Finance Corporation Limited (TRICOR) is providing Skill Development Program to tribes on various activities for creating the employment. The present study is an attempt to examine the perceptions of tribal women on skills for employment provided by TRICOR in Ranga Reddy district. Majority of the beneficiaries were expressed that the Skill Development Program was good. Even though, the program was good the tribal women are facing some problems after taking the training of skill development program. It is high time that the TRICOR need to put more attention on not only providing the Skill Development Program but also required to solve the problems of tribal women while implementing the programs.

Keywords: tribal women; employment; skill development; inclusive growth 


\section{Opportunities for the promotion of employability skills among the tribal women in Telangana state}

\section{Introduction}

Unemployment is one of the major problems in India. Every year thousands of students are coming into the real world for the jobs after their studies. Only few students are getting the jobs and the rest of them struggling a lot to get the employment. The problem is they do not have proper required skills for the employment. During the study period the educational institutions were not providing proper environment, training and skills to the students for getting the employment. The Telangana State Government is strongly focused on empowerment of tribal women especially in terms of creating the employment opportunities. Telangana State Scheduled Tribes Co-operative Finance Corporation Ltd (TRICOR) is providing Skill Development Program to tribes on various activities for creating the employment. The districts of Khammam, Warangal, and Adilabad where Integrated Tribal Development Agencies (ITDAs) are established functioning very seriously for poverty alleviation programs are implemented by these ITDAs. In all the other districts in the state District Level Committees (DLCs) are formed with the District Collector as the Chairman and District Tribal Welfare Officer (DTWO) as the Member Secretary for implementing poverty alleviation programs. Separate ITDA for chenchus was also established with its headquarters in Mannanurof Mahaboobnagardistrict for the development of Chenchus living in Mahaboobnagar, Nalgonda and Ranga Reddy districts. The Project Officers of MADA in the districts of Nalgonda and Mahaboobnagar, besides District Tribal Welfare Officers will look after Economic Support Schemes meant for STs.

The TRICOR head office formulates the policies in terms of preparing Annual Action Plans and monitors the implementation of schemes by way of convening review meetings while obtaining monthly progress reports. The Corporation mobilizes the financial resources form State and Central Government and other financial institutions and in turn releases to ITDAs/District Level Committees (DLCs) for implementation of schemes, besides mobilizing 6\% earmarked funds from the local bodies, the institutional finances from banks and $12 \%$ from TSP (Tribal Sub-Plan) from line Departments. The Managing Director manages the affairs of the Corporation under the guidance of the governing body of TRICOR.

\subsection{Challenges in Employability}

In the competitive world there are many challenges in employability. New and smart skills required to sustain in the global world.

$>$ Globalization and competition

$>\quad$ High cost of amount required for trainings

$>$ High time duration

$>\quad$ Shortage of skilled labor

$>\quad$ Day to day update the technological changes

$>$ High standards of quality

$>$ Automation in production

$>$ Cost cutting and more working hours

\section{Review of Literature}

Sharma and Rani (2009) accomplished an analysis which provides a comprehensive contraceptive use status among ST of Central India. An attempt is also made to know how far scheduled tribes differ from non-tribes using District Level Health Survey (DLHS-RCH II, 2002-04) round II data. Shows about 82 percent of current users in tribal population were sterilization users only. Bi-variate results show that use of sterilization increases with age of women, marital duration, female literacy, and number of surviving male child. While, Pandey (2011) 
concluded on socio-economic status of tribal women, the ecological and environmental factors existing in Bharmour have given to Gaddi women a special economic power, an elevated social status and authority almost equal to men. However, there are certain domains in which men continue to dominate, as is culturally required. Moreover, community authority still is in the hands of men. There is a kind of duality observed here. Men dominate in public and community affairs and continue to play the role of the head of the family and bread winner, women enjoy greater say in family life, great deal of social freedom and several of their actions are condoned/tolerated.

In addition, Das (2012) assessed the level of autonomy and decision making power of tribal women. Traditionally women have always been subjugated. True development of a nation is not possible if one half of the population is ignored or marginalized. The tribal women are enjoying the autonomy at their household level, especially in social aspects and enjoys the equal rights along with their husbands in economic matter related things however their community participation was passive and autonomy level was very low. While, Salehin (2012) found that social and ecological factors are more influential than economic and power factor in determining tribal women's reproductive health outcomes. Overall, the results of the study partially support the proposed model. Implications for social work practice, policy, and research were discussed.

Pulla (2013) also stated that the socioeconomic status of the scheduled tribes in Visakhapatnam district of Andhra Pradesh State, India. The majority of the households is the tribe of Konda Dora. The majority of the sample households in the study area are Hindus and more than 70 percent of the sample population is illiterate. Cultivation is the primary occupation participated by the most heads of the sample households. Agriculture income is the major source to the sample population. More than 53 percent of the cultivators have farm income around ₹ 2,000.00 to ₹ 5,000.00. Similarly, Pallavi and Nagaraja (2013) studied the economic status of tribal women; especially they are representatives of Panchayat Raj Institutions (PRIs). Concluded that if women are economically strong it creates leadership and decision making power. Constitutions safeguards to tribal women provided opportunity to enjoy more freedom and power than ever before. Still rural women require awareness in all aspects. Women are deprived of equal access to education, health care, capital. There is a strong need of economic empowerment through education, employment. Then she will get decision making powers in the political, social, and in other sectors.

Dhanasree, Vijayabhinandana, and Pradeepkumar (2014) conducted in tribal dominated mandals of High Altitude and Tribal Zone of Andhra Pradesh. With the help of exploratory research design, data was collected from 180 farmers and analyzed with the help of suitable statistical methods. Tribal women are playing very significant role in the economic development of tribes as they contribute in various economic activities. Women's work is regarded as crucial for the survival of tribal households in terms of provisioning food, income, creation of assets, earning and management of financial resources. While, Naresh (2014) discussed work participation of tribal women in India in a descriptive manner. The tribal women have been equal partners with tribal men in the contribution to household economy. Quite often their women do more physical labor in their agricultural fields and forest than that of the tribal men. Tribal women have usually enjoyed a higher social status in their own communities than Indian women in general. Some of the tribes like Khasi in Mizoram and Meghalaya are matriarchal. However, the literacy rate among the tribal's and more so in case of tribal women is quite low and this is also associated with poor nutritional and health status among the tribal's.

Chatterjee (2014) find out the challenges faced by tribal women, and discussed the strategies that they can consider for handling these challenges successfully. The findings can be beneficial for implementing projects that can help in improving their situation of backwardness. Further, Bhukya (2015) concluded the empowerment for women in India requires a crosscutting approach and one which addresses the diversity of social structures that govern women's lives. Identity politics in India is a very critical political instrument, which is both used and abused throughout political and social institutions. There are numerous social movements fighting for the rights of the marginalized, such as the Dalit rights movement, and the tribal rights movement. Lastly, Lagachu (2016) attempted the importance of education and the problem facing among the tribal women and also highlights with 
Penumala, V. K., \& Malyadri, P.

finding and some suggestive measures about the values of education and needs of quality education in day to day life of the tribal women.

All the previous studies pertaining to economic development of tribes, tribal women health, economic empower, socio economic status, decision making power, social work practice, income levels of tribal women, challenges faced by tribal women and problems in tribal education and many others. These studies were not covered the various opportunities for employability skills among the tribal women. The present study is going in this direction.

\section{Methodology}

\subsection{Objectives of the Study}

$>$ To overview of Skill Development Programs provided by TRICOR

$>$ To examine the perceptions of tribal women on Skill Development Program provided by TRICOR

\subsection{Data Collection}

The study is an exploratory of primary data and secondary data. Primary data has been obtained from selected beneficiaries through structured questionnaire. The secondary data has been obtained from various published sources and electronic media.

\subsection{Sampling Method}

Multistage sampling method has been selected for the selection of sample beneficiaries. Telangana State is purposively selected for the present research study. Telangana State Scheduled Tribe Co-operative Finance Corporation Limited (TRICOR) which is located in Hyderabad has been selected for drawing the list of sample tribal beneficiaries as the TRICOR is providing number Skill Development Programs for the employment generation. There are 10 districts in Telangana state, among the districts Ranga Reddy district has been selected as it is providing number of employment opportunities in this district. Five major Skill Development Programs selected which are providing more number of employment opportunities for Tribal women. 10 beneficiaries had been selected from each Skill development program. Hence the total sample size was $50(5 \times 10=50)$ beneficiaries. The sample size is moderate and reliable representative by keeping in view Skill Development Program. It was convenient for comparison and making fruitful conclusion.

The below mentioned are the schemes of TRICOR has been selected for this study

$>$ Hotel Management and Hospitality (HM\&H)

$>\quad$ Lab Technician (LT)

$>\quad$ Tailoring and Embroidering (T\&E)

$>$ Manufacturing of Sentry Napkin (MSN)

$>$ Business Process Outsourcing (BPO)

\subsection{Tools for Analysis}

The data had been analyzed and interpreted with the help of Statistical Package for Social Sciences (SPSS-16.0) was used to the results. The tools are used for analysis are sum, percentage, and chi-square test.

\subsection{Hypothesis Testing}

There is no significant difference of perceptions among the tribal women on Skill Development Program of TRICOR. 
3.6 Scope of the Study

The scope of the study was the existing Skill Development Programs of TRICOR in Ranga Reddy district of Telangana state.

\subsection{Limitations of the Study}

The study has been covered only one selected district of Telangana state.

\subsection{Implications of the study}

The study will be useful to the tribes, Govt, bankers, researchers, policy makers, Ministry of tribal welfare department, Ministry of planning commission, Administrators, NGOs and TRICOR etc.

\section{Telangana State Tribes Cooperative Finance Corporation Limited (TRICOR)}

Andhra Pradesh State Scheduled Tribes Co-operative Finance Corporation Limited (AP TRICOR), Hyderabad was established in October, 1976 under A.P Co-operative Societies Act 1964 with registration No.T.A.843 with a share holding pattern of 51:49 percent between the state and central government respectively. As per the government policy decision the AP TRICOR should not be a lending agency but shall act as facilitator by providing subsidy on the unit costs, to undertake specific activities for implementation of Economic Support Schemes for the development of poorest of poor Scheduled Tribes (STs) in the fields of Agriculture, Horticulture, Animal Husbandry, Skill Development and ISB (Industry Service and Business) Sectors.

\subsection{A.P Reorganization Act 2014}

The A.P Reorganization Act 2014 came in to existence with effect from $18^{\text {th }}$, March, 2014. The Act came into being from the appointed day of $2^{\text {nd }}$, June, 2014. Accordingly a new state is framed by the name State of Telangana comprising ten (10) districts viz; Adilabad, Khammam, Warangal, Mahabubnagar, Karimnagar, Nizamabad, Nalgonda, Medak, Ranga Reddy and Hyderabad. The Telangana State Tribes Cooperative Finance Corporation Ltd (TS TRICOR), Hyderabad is one among (89) Corporations included in the IX Schedule.

\subsection{Perception of TRICOR}

$>$ Socio-economic development of STs Leading to golden threshold of improved livelihood condition.

$>$ Empowering ST women, SHG for collective action with enhancing bargaining capacity.

$>\quad$ Skill up gradation to access self/wage employment to improve quality of life.

\subsection{Mission}

The mission is to provide financial assistance for creation of income generating assets to the poor Scheduled Tribe households for their Socio-economic Development.

\subsection{Objectives of TS TRICOR}

TS TRICOR focus its aim at providing financial assistance to enable the poorest of poor Scheduled Tribe beneficiaries to mobilize the required institutional credit to take up the income generating economic activities, besides the Corporation aims at mobilizing financial resources from the agencies involved in the poverty alleviation programs as well as institutional finance from Commercial Banks, A.P State Finance Corporation, Regional Rural Banks and Co-operative Societies. The following are the objectives in brief:

All round development of STs in the State with special focus on Tribal Sub Plan areas.

$>\quad$ To provide financial assistance to ST families below poverty line to take up Economic Support Scheme. 
$>\quad$ To provide financial assistance to STs for creation of income generating assets.

$>\quad$ To provide training programs for skill up gradation paving way for self/wage employment.

$>\quad$ To empower ST women self help groups for taking up Economic Support Schemes.

$>\quad$ To plug critical gaps of finance in Economic Support Scheme.

\subsection{Skill Development Program}

Separate Sub Mission was constituted for STs for implementation of Skill Development initiatives in the Scheduled Areas of Telangana State.

\subsection{Strategy and progress of implementation}

Organizing Bhavitha Orientation trainings to tribal youth to create awareness on wage employment, self employment and formal employment opportunities. This program is being conducted at Mandal levels.

$>\quad$ Counselling, assessment and preparation of individual plan for employment and preparation of resume and email accounts are opened in respect of the ST youth attended Bhavitha.

$>\quad$ To analyze the suitability of ST youth for Government/Private/Self Employment and to extend required support.

$>$ Organising Direct Placement drives in tribal areas.

$>\quad$ Imparting placement linked training to ST youth for up gradation of their skills.

\subsection{Progress in Telangana State}

$>\quad$ During 2013-14, 5348 ST youth were trained and 4828 ST youth were provided employment, of which 4006 are working against the Telangana target of 6180 i.e., $87 \%$ of achievement.

$>\quad$ For the year 2014-15, it is proposed to provide employment to (4500) ST youth. So far (2873) ST youth provided employment by organizing training and direct placement drives.

$>\quad$ During the year 2015-16, so far (1668) ST youth provided employment in various Private Organisations through Trainings \& Placements and by organising (21) Direct placement drives.

\subsection{Initiatives}

$>\quad$ Entrepreneurship Development Program at Aadhivasi building, Bhadrachalam \& YTC Yellandhu. So far (1768) ST beneficiaries have been trained.

$>\quad$ Self Employment trainings through Association of Lady Entrepreneurs of AP (ALEAP)

$>\quad$ Placement linked trainings through Central Institute of Plastic Engineering \& Technology (CIPET).

$>$ Entrepreneurial Development Training Program through National Academy of Construction (NAC), Hyderabad.

$>$ Driving training through TSRTC

$>\quad$ Youth Training Centres (YTC)

\section{Table 1}

Skill Development Programs of TRICOR

\begin{tabular}{ll}
\hline \multicolumn{1}{c}{ Sl. No } & \multicolumn{1}{c}{ Skill Development Program } \\
\hline 1 & 2 \& 3 Wheeler mechanic \\
2 & Agarbathi production \\
3 & B.P.O (Business Process Outsourcing) \\
4 & Cell phone repairing \& Services \\
5 & Computer hardware and software \\
6 & Electrical \& Housing Wiring \\
7 & Heavy Motor Vehicle \\
8 & Hotel Management \& Hospitality \\
9 & Income Generating \& Skill Development Training Programs \\
10 & Lab-Technician \\
\hline
\end{tabular}


Table 1...continued

\begin{tabular}{cl}
\hline Sl. No & \multicolumn{1}{c}{ Skill Development Program } \\
\hline 11 & Light Motor Vehicle \\
12 & Motor Rewinding \\
13 & Paper plate making \\
14 & Plumbing \& sanitation \\
15 & Sanitary Napkin \\
16 & Tailoring \& Embroidery \\
\hline Source: TRICOR action plans 2015-16, Government of Telangana State.
\end{tabular}

Table 1 shows the Skill Development Programs of TRICOR in Telangana State.

\section{Table 2}

Beneficiaries' perceptions on Facilities at Training Centre

\begin{tabular}{|c|c|c|c|c|c|c|c|c|}
\hline \multirow{2}{*}{$\begin{array}{c}\text { Facilities at } \\
\text { Training Centre }\end{array}$} & \multicolumn{5}{|c|}{ Skill Development Programs } & \multirow{2}{*}{ Total } & \multirow{2}{*}{$\chi^{2}$} & \multirow{2}{*}{$d f$} \\
\hline & $\mathrm{HM} \& \mathrm{H}$ & LT & $\mathrm{T} \& \mathrm{E}$ & MSN & $\mathrm{BPO}$ & & & \\
\hline \multirow[t]{2}{*}{ Very Good } & 2 & 1 & 0 & 1 & 0 & 4 & 0.996 & 16 \\
\hline & (4) & $(2)$ & $(0)$ & (2) & $(0)$ & (8) & & \\
\hline \multirow[t]{2}{*}{ Good } & 3 & 3 & 4 & 3 & 4 & 17 & & \\
\hline & (6) & $(6)$ & $(8)$ & (6) & (8) & $(34)$ & & \\
\hline \multirow[t]{2}{*}{ Average } & 4 & 4 & 4 & 4 & 4 & 20 & & \\
\hline & (8) & (8) & $(8)$ & $(8)$ & (8) & $(40)$ & & \\
\hline \multirow[t]{2}{*}{ Below Average } & 1 & 1 & 1 & 1 & 1 & 5 & & \\
\hline & (2) & (2) & (2) & (2) & (2) & (10) & & \\
\hline \multirow[t]{2}{*}{ Poor } & 0 & 1 & 1 & 1 & 1 & 4 & & \\
\hline & $(0)$ & $(2)$ & (2) & (2) & (2) & (8) & & \\
\hline \multirow[t]{2}{*}{ Total } & 10 & 10 & 10 & 10 & 10 & $50(100)$ & & \\
\hline & (20) & $(20)$ & $(20)$ & $(20)$ & $(20)$ & & & \\
\hline
\end{tabular}

Source. Field data.

Note. The figures in the brackets are percentages to the total.

Table 2 explains the beneficiaries' perceptions on Facilities at Training Centers. Majorly 20 (40 percent) beneficiaries' perceptions were average followed by 17 (34 percent) beneficiaries perceptions were good. Only 4 ( 8 percent) beneficiaries' perceptions were very good followed by 4 ( 8 percent) beneficiaries were poor on Facilities at Training Centers. The $p$ value 0.996 is greater than the value 0.05 at the 5 percent level of significance; hence the null hypothesis was rejected. It's indicated that there is a significant difference of perceptions on Facilities at Training Centers among the tribal women.

Table 3

Beneficiaries' perceptions on Training of Trainer

\begin{tabular}{|c|c|c|c|c|c|c|c|c|}
\hline \multirow{2}{*}{$\begin{array}{c}\text { Training of } \\
\text { Trainer }\end{array}$} & \multicolumn{5}{|c|}{ Skill Development Programs } & \multirow[t]{2}{*}{ Total } & \multirow[t]{2}{*}{$\chi^{2}$} & \multirow[t]{2}{*}{$d f$} \\
\hline & $\mathrm{HM} \& \mathrm{H}$ & LT & T\&E & MSN & $\mathrm{BPO}$ & & & \\
\hline \multirow[t]{2}{*}{ Very Good } & 2 & 0 & 1 & 2 & 0 & 5 & 0.137 & 16 \\
\hline & (4) & $(0)$ & (2) & (4) & $(0)$ & (10) & & \\
\hline \multirow[t]{2}{*}{ Good } & 6 & 3 & 3 & 3 & 2 & 17 & & \\
\hline & (12) & (6) & (6) & (6) & (4) & (34) & & \\
\hline \multirow[t]{2}{*}{ Average } & 1 & 6 & 3 & 2 & 8 & 20 & & \\
\hline & (2) & $(12)$ & (6) & (4) & $(16)$ & (40) & & \\
\hline \multirow[t]{2}{*}{ Below Average } & 1 & 1 & 1 & 1 & 0 & 4 & & \\
\hline & (2) & (2) & (2) & (2) & (0) & (8) & & \\
\hline \multirow[t]{2}{*}{ Poor } & 0 & 0 & 2 & 2 & 0 & 4 & & \\
\hline & (0) & (0) & (4) & (4) & (0) & (8) & & \\
\hline \multirow[t]{2}{*}{ Total } & 10 & 10 & 10 & 10 & 10 & $50(100)$ & & \\
\hline & $(20)$ & $(20)$ & $(20)$ & $(20)$ & $(20)$ & & & \\
\hline
\end{tabular}

Source. Field data.

Note. The figures in the brackets are percentages to the total. 
Penumala, V. K., \& Malyadri, P.

Table 3 explains the beneficiaries' perceptions on Training of Trainer. Majorly 20 (40 percent) beneficiaries' perceptions were average followed by 17 (34 percent) beneficiaries perceptions were good. Only 4 ( 8 percent) beneficiaries' perceptions were below average followed by 4 ( 8 percent) beneficiaries were poor on Training of Trainer. The $p$ value 0.137 is greater than the value 0.05 at the 5 percent level of significance; hence the null hypothesis was rejected. It's indicated that there is a significant difference of perceptions on Training of Trainer among the tribal women.

\section{Table 4}

Beneficiaries' perceptions on Understanding of Training

\begin{tabular}{|c|c|c|c|c|c|c|c|c|}
\hline \multirow{2}{*}{$\begin{array}{c}\text { Trainee } \\
\text { Understanding }\end{array}$} & \multicolumn{5}{|c|}{ Skill Development Programs } & \multirow{2}{*}{ Total } & \multirow{2}{*}{$\chi^{2}$} & \multirow{2}{*}{$d f$} \\
\hline & HM\&H & LT & T\&E & MSN & $\mathrm{BPO}$ & & & \\
\hline Very Good & $\begin{array}{c}2 \\
(4)\end{array}$ & $\begin{array}{c}5 \\
(10)\end{array}$ & $\begin{array}{c}6 \\
(12)\end{array}$ & $\begin{array}{c}2 \\
(4)\end{array}$ & $\begin{array}{c}5 \\
(10)\end{array}$ & $\begin{array}{c}20 \\
(40)\end{array}$ & 0.451 & 16 \\
\hline Good & $\begin{array}{c}3 \\
(6)\end{array}$ & $\begin{array}{c}3 \\
(6)\end{array}$ & $\begin{array}{l}3 \\
(6)\end{array}$ & $\begin{array}{l}1 \\
(2)\end{array}$ & $\begin{array}{c}4 \\
(8)\end{array}$ & $\begin{array}{l}14 \\
(28)\end{array}$ & & \\
\hline Average & $\begin{array}{c}3 \\
(6)\end{array}$ & $\begin{array}{l}1 \\
(2)\end{array}$ & $\begin{array}{l}1 \\
(2)\end{array}$ & $\begin{array}{c}5 \\
(10)\end{array}$ & $\begin{array}{l}1 \\
(2)\end{array}$ & $\begin{array}{l}11 \\
(22)\end{array}$ & & \\
\hline Below Average & $\begin{array}{l}1 \\
(2)\end{array}$ & $\begin{array}{l}1 \\
(2)\end{array}$ & $\begin{array}{l}0 \\
(0)\end{array}$ & $\begin{array}{l}1 \\
(2)\end{array}$ & $\begin{array}{c}0 \\
(0)\end{array}$ & $\begin{array}{c}3 \\
(6)\end{array}$ & & \\
\hline Poor & $\begin{array}{l}1 \\
(2)\end{array}$ & $\begin{array}{c}0 \\
(0)\end{array}$ & $\begin{array}{l}0 \\
(0)\end{array}$ & $\begin{array}{l}1 \\
(2)\end{array}$ & $\begin{array}{c}0 \\
(0)\end{array}$ & $\begin{array}{c}2 \\
(4)\end{array}$ & & \\
\hline Total & $\begin{array}{l}10 \\
(20)\end{array}$ & $\begin{array}{l}10 \\
(20)\end{array}$ & $\begin{array}{c}10 \\
(20)\end{array}$ & $\begin{array}{c}10 \\
(20)\end{array}$ & $\begin{array}{c}10 \\
(20)\end{array}$ & $50(100)$ & & \\
\hline
\end{tabular}

Source. Field data.

Note. The figures in the brackets are percentages to the total.

Table 4 shows the beneficiaries' perceptions on understanding of training. Majorly 20 (40 percent) beneficiaries' perceptions were very good followed by 14 ( 28 percent) beneficiaries perceptions were good. Only 2 (4 percent) beneficiaries' perceptions were poor on understanding of training. The $p$ value 0.451 is greater than the value 0.05 at the 5 percent level of significance; hence the null hypothesis was rejected. It's indicated that there is a significant difference of perceptions on understanding of training among the tribal women.

\section{Table 5}

Beneficiaries' perceptions on Usefulness of Training in practice

\begin{tabular}{|c|c|c|c|c|c|c|c|c|}
\hline \multirow{2}{*}{$\begin{array}{l}\text { Usefulness of } \\
\text { Training in } \\
\text { practise }\end{array}$} & \multicolumn{5}{|c|}{ Skill Development Programs } & \multirow[b]{2}{*}{ Total } & \multirow[b]{2}{*}{$\chi^{2}$} & \multirow[b]{2}{*}{$d f$} \\
\hline & $\mathrm{HM} \& \mathrm{H}$ & $\mathrm{LT}$ & $\mathrm{T} \& \mathrm{E}$ & MSN & $\mathrm{BPO}$ & & & \\
\hline Very Good & $\begin{array}{c}4 \\
(8)\end{array}$ & $\begin{array}{c}2 \\
(4)\end{array}$ & $\begin{array}{c}3 \\
(6)\end{array}$ & $1(2)$ & $\begin{array}{c}4 \\
(8)\end{array}$ & $\begin{array}{c}14 \\
(28)\end{array}$ & 0.355 & 16 \\
\hline Good & $\begin{array}{c}2 \\
(4)\end{array}$ & $\begin{array}{c}4 \\
(8)\end{array}$ & $\begin{array}{c}3 \\
(6)\end{array}$ & $3(6)$ & $\begin{array}{l}1 \\
(2)\end{array}$ & $\begin{array}{l}13 \\
(26)\end{array}$ & & \\
\hline Average & $\begin{array}{l}1 \\
\text { (2) }\end{array}$ & $\begin{array}{c}2 \\
(4)\end{array}$ & $\begin{array}{c}3 \\
(6)\end{array}$ & $6(12)$ & $\begin{array}{c}5 \\
(10)\end{array}$ & $\begin{array}{c}17 \\
(34)\end{array}$ & & \\
\hline Below Average & $\begin{array}{c}2 \\
(4)\end{array}$ & $\begin{array}{c}2 \\
(4)\end{array}$ & $\begin{array}{c}1 \\
(2)\end{array}$ & $0(0)$ & $\begin{array}{c}0 \\
(0)\end{array}$ & $\begin{array}{c}5 \\
(10)\end{array}$ & & \\
\hline Poor & $\begin{array}{c}1 \\
(2)\end{array}$ & $\begin{array}{c}0 \\
(0)\end{array}$ & $\begin{array}{c}0 \\
(0)\end{array}$ & $0(0)$ & $\begin{array}{c}0 \\
(0)\end{array}$ & $\begin{array}{c}1 \\
(2)\end{array}$ & & \\
\hline Total & $\begin{array}{c}10 \\
(20)\end{array}$ & $\begin{array}{c}10 \\
(20)\end{array}$ & $\begin{array}{c}10 \\
(20)\end{array}$ & $\begin{array}{c}10 \\
(20)\end{array}$ & $\begin{array}{c}10 \\
(20)\end{array}$ & $50(100)$ & & \\
\hline
\end{tabular}

Note. The figures in the brackets are percentages to the total.

Table 5 evident the beneficiaries' perceptions on Usefulness of Training in practice. Majorly 17 (34 percent) beneficiaries' perceptions were average followed by 14 (28 percent) beneficiaries perceptions were very good. Only 1 ( 2 percent) beneficiaries' perceptions were poor on Usefulness of Training in practice. The $p$ value 0.355 is greater than the value 0.05 at the 5 percent level of significance; hence the null hypothesis was rejected. It's 
Opportunities for the promotion of employability skills among the tribal women in Telangana state

indicated that there is a significant difference of perceptions on Usefulness of Training in practice among the tribal women.

\section{Table 6}

Beneficiaries' perceptions on Socio-Economic life in Post Training

\begin{tabular}{|c|c|c|c|c|c|c|c|c|}
\hline \multirow{2}{*}{$\begin{array}{c}\text { Socio-Economic } \\
\text { life in Post } \\
\text { Training }\end{array}$} & \multicolumn{5}{|c|}{ Skill Development Programs } & \multirow[b]{2}{*}{ Total } & \multirow[b]{2}{*}{$\chi^{2}$} & \multirow[b]{2}{*}{$d f$} \\
\hline & $\mathrm{HM} \& \mathrm{H}$ & LT & $\mathrm{T} \& \mathrm{E}$ & MSN & $\mathrm{BPO}$ & & & \\
\hline Very Good & $\begin{array}{c}5 \\
(10)\end{array}$ & $\begin{array}{c}3 \\
(6)\end{array}$ & $\begin{array}{c}4 \\
(8)\end{array}$ & $\begin{array}{c}3 \\
(6)\end{array}$ & $\begin{array}{c}4 \\
(8)\end{array}$ & $\begin{array}{c}19 \\
(38)\end{array}$ & 0.783 & 16 \\
\hline Good & $\begin{array}{c}3 \\
(6)\end{array}$ & $\begin{array}{c}4 \\
(8)\end{array}$ & $\begin{array}{c}4 \\
(8)\end{array}$ & $\begin{array}{c}3 \\
(6)\end{array}$ & $\begin{array}{c}3 \\
(6)\end{array}$ & $\begin{array}{c}17 \\
(34)\end{array}$ & & \\
\hline Average & $\begin{array}{c}2 \\
(4)\end{array}$ & $\begin{array}{c}1 \\
(2)\end{array}$ & $\begin{array}{c}2 \\
(4)\end{array}$ & $\begin{array}{c}2 \\
(4)\end{array}$ & $\begin{array}{c}3 \\
(6)\end{array}$ & $\begin{array}{c}10 \\
(20)\end{array}$ & & \\
\hline Below Average & $\begin{array}{c}0 \\
(0)\end{array}$ & $\begin{array}{c}1 \\
(2)\end{array}$ & $\begin{array}{c}0 \\
(0)\end{array}$ & $\begin{array}{c}2 \\
(4)\end{array}$ & $\begin{array}{c}0 \\
(0)\end{array}$ & $\begin{array}{c}3 \\
(6)\end{array}$ & & \\
\hline Poor & $\begin{array}{c}0 \\
(0)\end{array}$ & $\begin{array}{c}1 \\
(2)\end{array}$ & $\begin{array}{c}0 \\
(0)\end{array}$ & $\begin{array}{c}0 \\
(0)\end{array}$ & $\begin{array}{c}0 \\
(0)\end{array}$ & $\begin{array}{c}1 \\
(2)\end{array}$ & & \\
\hline Total & $\begin{array}{c}10 \\
(20)\end{array}$ & $\begin{array}{c}10 \\
(20)\end{array}$ & $\begin{array}{c}10 \\
(20)\end{array}$ & $\begin{array}{c}10 \\
(20)\end{array}$ & $\begin{array}{c}10 \\
(20)\end{array}$ & $50(100)$ & & \\
\hline
\end{tabular}

Source. Field data.

Note. The figures in the brackets are percentages to the total.

Table 6 explains the beneficiaries' perceptions on Socio-Economic life in Post Training. Majorly 19 (38 percent) beneficiaries' perceptions were very good followed by 17 (34 percent) beneficiaries perceptions were good. Only 1 ( 2 percent) beneficiaries' perceptions were poor on Socio-Economic life in Post Training. The $p$ value 0.783 is greater than the value 0.05 at the 5 percent level of significance; hence the null hypothesis was rejected. It's indicated that there is a significant difference of perceptions on Socio-Economic life in Post Training among the tribal women.

Table 7

Time taken to beneficiaries for Job opportunity/ self employment loan

\begin{tabular}{|c|c|c|c|c|c|c|c|c|}
\hline \multirow{2}{*}{$\begin{array}{c}\text { Time taken for Job } \\
\text { opportunity/ } \\
\text { self-employment loan }\end{array}$} & \multicolumn{5}{|c|}{ Skill Development Programs } & \multirow{2}{*}{ Total } & \multirow[b]{2}{*}{$\chi^{2}$} & \multirow[b]{2}{*}{$d f$} \\
\hline & $\mathrm{HM} \& \mathrm{H}$ & $\mathrm{LT}$ & $\mathrm{T} \& \mathrm{E}$ & MSN & $\mathrm{BPO}$ & & & \\
\hline Below One Month & $\begin{array}{c}0 \\
(0)\end{array}$ & $\begin{array}{c}1 \\
(2)\end{array}$ & $\begin{array}{c}8 \\
(16)\end{array}$ & $\begin{array}{c}0 \\
(0)\end{array}$ & $\begin{array}{c}3 \\
(6)\end{array}$ & $12(24)$ & 0 & 12 \\
\hline 1-2 Months & $\begin{array}{c}0 \\
(0)\end{array}$ & $\begin{array}{c}3 \\
(6)\end{array}$ & $\begin{array}{c}2 \\
(4)\end{array}$ & $\begin{array}{c}1 \\
(2)\end{array}$ & $\begin{array}{c}3 \\
(6)\end{array}$ & $\begin{array}{c}9 \\
(18)\end{array}$ & & \\
\hline 2-3 Months & $\begin{array}{c}8 \\
(16)\end{array}$ & $\begin{array}{c}4 \\
(8)\end{array}$ & $\begin{array}{c}0 \\
(0)\end{array}$ & $\begin{array}{c}4 \\
(8)\end{array}$ & $\begin{array}{c}2 \\
(4)\end{array}$ & $18(36)$ & & \\
\hline Four Months and above & $\begin{array}{c}2 \\
(4)\end{array}$ & $\begin{array}{c}2 \\
(4)\end{array}$ & $\begin{array}{c}0 \\
(0)\end{array}$ & $\begin{array}{c}5 \\
(10)\end{array}$ & $\begin{array}{c}2 \\
(4)\end{array}$ & $11(22)$ & & \\
\hline Total & $\begin{array}{c}10 \\
(20)\end{array}$ & $10(20)$ & $10(20)$ & $10(20)$ & $10(20)$ & $50(100)$ & & \\
\hline
\end{tabular}

Source. Field data.

Note. The figures in the brackets are percentages to the total.

Table 7 shows the time taken to beneficiaries for Job opportunity/ self employment loan from bank or TRICOR. Majorly 18 beneficiaries (36 percent) said two to three months time followed by 11(22 percent) beneficiaries said four and more than four months time taken to beneficiaries for Job opportunity/ self employment loan from bank or TRICOR. The $p$ value 0.000 is less than the value 0.05 at the 5 percent level of significance; hence the null hypothesis was accepted. It's indicated that there is no significant difference in time taken to beneficiaries for Job opportunity/ self employment loan from bank or TRICOR among the tribal women. 
Penumala, V. K., \& Malyadri, P.

\section{Table 8}

Time taken to selecting the beneficiaries for Skill Development Program

\begin{tabular}{|c|c|c|c|c|c|c|c|c|}
\hline \multirow{2}{*}{$\begin{array}{l}\text { Time Taken to Select } \\
\text { the beneficiaries }\end{array}$} & \multicolumn{5}{|c|}{ Skill Development Programs } & \multirow{2}{*}{ Total } & \multirow{2}{*}{$\chi^{2}$} & \multirow{2}{*}{$d f$} \\
\hline & $\mathrm{HM} \& \mathrm{H}$ & LT & $\mathrm{T} \& \mathrm{E}$ & MSN & BPO & & & \\
\hline Below One Month & $\begin{array}{l}1 \\
(2)\end{array}$ & $\begin{array}{c}1 \\
(2)\end{array}$ & $\begin{array}{l}1 \\
(2)\end{array}$ & $\begin{array}{c}0 \\
(0)\end{array}$ & $\begin{array}{c}1 \\
(2)\end{array}$ & $\begin{array}{c}4 \\
(8)\end{array}$ & 0.987 & 12 \\
\hline 1-2 Months & $\begin{array}{c}2 \\
(4)\end{array}$ & $\begin{array}{c}2 \\
(4)\end{array}$ & $\begin{array}{c}2 \\
(4)\end{array}$ & $\begin{array}{c}1 \\
(2)\end{array}$ & $\begin{array}{c}3 \\
(6)\end{array}$ & $10(20)$ & & \\
\hline 2-3 Months & $\begin{array}{c}4 \\
(8)\end{array}$ & $\begin{array}{l}3 \\
(6)\end{array}$ & $\begin{array}{l}3 \\
(6)\end{array}$ & $\begin{array}{c}4 \\
(8)\end{array}$ & $\begin{array}{c}4 \\
(8)\end{array}$ & $18(36)$ & & \\
\hline Four Months and above & $\begin{array}{c}3 \\
(6)\end{array}$ & $\begin{array}{c}4 \\
(8)\end{array}$ & $\begin{array}{c}4 \\
(8)\end{array}$ & $\begin{array}{c}5 \\
(10)\end{array}$ & $\begin{array}{c}2 \\
(4)\end{array}$ & $18(36)$ & & \\
\hline Total & $\begin{array}{c}10 \\
(20)\end{array}$ & $10(20)$ & $10(20)$ & $10(20)$ & $10(20)$ & $50(100)$ & & \\
\hline
\end{tabular}

Source. Field data.

Note. The figures in the brackets are percentages to the total.

Table 8 explains about time taken to selecting the beneficiaries for Skill Development Program. Majorly 18 beneficiaries (36 percent) said two to three months time followed by 18(36 percent) beneficiaries said four and more than four months time taken to selecting the beneficiaries for Skill Development Program. The $p$ value 0.987 is greater than the value 0.05 at the 5 percent level of significance; hence the null hypothesis was rejected. It's indicated that there is a significant difference in time taken to selecting the beneficiaries for Skill Development Program among the tribal women.

Table 9

Beneficiaries' perception on enough time in training period to learn the course

\begin{tabular}{|c|c|c|c|c|c|c|c|c|}
\hline \multirow{2}{*}{$\begin{array}{l}\text { Training period is } \\
\text { enough to learn the } \\
\text { training program }\end{array}$} & \multicolumn{5}{|c|}{ Skill Development Programs } & \multirow[b]{2}{*}{ Total } & \multirow[b]{2}{*}{$\chi^{2}$} & \multirow[b]{2}{*}{$d f$} \\
\hline & $\mathrm{HM} \& \mathrm{H}$ & $\mathrm{LT}$ & $\mathrm{T} \& \mathrm{E}$ & MSN & $\mathrm{BPO}$ & & & \\
\hline Yes & $\begin{array}{c}3 \\
(6)\end{array}$ & $\begin{array}{c}4 \\
(8)\end{array}$ & $\begin{array}{c}3 \\
(6)\end{array}$ & $\begin{array}{c}5 \\
(10)\end{array}$ & $\begin{array}{c}3 \\
(6)\end{array}$ & $\begin{array}{c}18 \\
(36)\end{array}$ & 0.846 & 4 \\
\hline No & $\begin{array}{c}7 \\
(14)\end{array}$ & $\begin{array}{c}6 \\
(12)\end{array}$ & $\begin{array}{c}7 \\
(14)\end{array}$ & $\begin{array}{c}5 \\
(10)\end{array}$ & $\begin{array}{c}7 \\
(14)\end{array}$ & $\begin{array}{c}32 \\
(64)\end{array}$ & & \\
\hline Total & $\begin{array}{c}10 \\
(20)\end{array}$ & $\begin{array}{c}10 \\
(20) \\
\end{array}$ & $\begin{array}{c}10 \\
(20)\end{array}$ & $\begin{array}{c}10 \\
(20)\end{array}$ & $\begin{array}{c}10 \\
(20) \\
\end{array}$ & $50(100)$ & & \\
\hline
\end{tabular}

Source. Field data.

Note. The figures in the brackets are percentages to the total.

Table 9 shows the beneficiaries perception on enough time in training period to learn the course. Majorly 32 (64 percent) beneficiaries perception was the time was not enough to learn the training program. The $p$ value 0.846 is greater than the value 0.05 at the 5 percent level of significance; hence the null hypothesis was rejected. It's indicated that there is a significant difference of perceptions on enough time in training period to learn the course among the tribal women.

\section{Table 10}

Beneficiaries' perception on requirement of additional training

\begin{tabular}{|c|c|c|c|c|c|c|c|c|}
\hline \multirow{2}{*}{$\begin{array}{c}\text { Requirement of } \\
\text { additional training }\end{array}$} & \multicolumn{5}{|c|}{ Skill Development Programs } & \multirow{2}{*}{ Total } & \multirow{2}{*}{$\chi^{2}$} & \multirow{2}{*}{$d f$} \\
\hline & $\mathrm{HM} \& \mathrm{H}$ & LT & $\mathrm{T} \& \mathrm{E}$ & MSN & $\mathrm{BPO}$ & & & \\
\hline Yes & $\begin{array}{c}7 \\
(14)\end{array}$ & $\begin{array}{c}7 \\
(14)\end{array}$ & $\begin{array}{c}10 \\
(20)\end{array}$ & $\begin{array}{c}6 \\
(12)\end{array}$ & $\begin{array}{c}1 \\
(2)\end{array}$ & $\begin{array}{c}31 \\
(62)\end{array}$ & 0.001 & 4 \\
\hline No & $\begin{array}{c}3 \\
(6)\end{array}$ & $\begin{array}{l}3 \\
(6)\end{array}$ & $\begin{array}{c}0 \\
(0)\end{array}$ & $\begin{array}{c}4 \\
(8)\end{array}$ & $\begin{array}{c}9 \\
(18)\end{array}$ & $\begin{array}{c}19 \\
(38)\end{array}$ & & \\
\hline Total & $\begin{array}{c}10 \\
(20)\end{array}$ & $\begin{array}{c}10 \\
(20)\end{array}$ & $\begin{array}{l}10 \\
(20)\end{array}$ & $\begin{array}{c}10 \\
(20)\end{array}$ & $\begin{array}{c}10 \\
(20)\end{array}$ & $50(100)$ & & \\
\hline
\end{tabular}

Source. Field data.

Note. The figures in the brackets are percentages to the total. 
Table 10 explains the beneficiaries' perception on requirement of additional training. Majorly 31 (62 percent) beneficiaries' required the additional training. The $p$ value 0.001 is less than the value 0.05 at the 5 percent level of significance; hence the null hypothesis was accepted. It's indicated that there is no significant difference of perceptions on requirement of additional training among the tribal women.

\section{Table 11}

\begin{tabular}{|c|c|c|c|c|c|c|c|c|}
\hline \multirow{2}{*}{$\begin{array}{c}\text { TRICOR } \\
\text { Officials } \\
\text { visited in } \\
\text { post training }\end{array}$} & \multicolumn{5}{|c|}{ Skill Development Programs } & \multirow[b]{2}{*}{ Total } & \multirow[b]{2}{*}{$\chi^{2}$} & \multirow[b]{2}{*}{$d f$} \\
\hline & $\mathrm{HM} \& \mathrm{H}$ & $\mathrm{LT}$ & $\mathrm{T} \& \mathrm{E}$ & MSN & BPO & & & \\
\hline Yes & $\begin{array}{c}2 \\
(4)\end{array}$ & $\begin{array}{c}1 \\
(2)\end{array}$ & $\begin{array}{c}3 \\
(6)\end{array}$ & $\begin{array}{c}3 \\
(6)\end{array}$ & $\begin{array}{c}2 \\
(4)\end{array}$ & $\begin{array}{c}11 \\
(22)\end{array}$ & 0.803 & 4 \\
\hline No & $\begin{array}{c}8 \\
(16)\end{array}$ & $\begin{array}{c}9 \\
(18)\end{array}$ & $\begin{array}{c}7 \\
(14)\end{array}$ & $\begin{array}{c}7 \\
(14)\end{array}$ & $\begin{array}{c}8 \\
(16)\end{array}$ & $\begin{array}{c}39 \\
(78)\end{array}$ & & \\
\hline Total & $\begin{array}{c}10 \\
(20)\end{array}$ & $\begin{array}{c}10 \\
(20)\end{array}$ & $\begin{array}{c}10 \\
(20)\end{array}$ & $\begin{array}{c}10 \\
(20)\end{array}$ & $\begin{array}{c}10 \\
(20)\end{array}$ & $50(100)$ & & \\
\hline
\end{tabular}

\section{Source. Field data.}

Note. The figures in the brackets are percentages to the total.

Table 11 shows the beneficiaries perception on TRICOR Officials visited in post training. Majorly 39 (78 percent) beneficiaries said the TRICOR Officials not visited in post training. The $p$ value 0.803 is greater than the value 0.05 at the 5 percent level of significance; hence the null hypothesis was rejected. It's indicated that there is no significant difference of perceptions on TRICOR Officials visited in post training among the tribal women.

\section{Conclusion}

The TRICOR is providing the good training facilities for Skill Development Program in Ranga Reddy District. The tribal women are getting employment opportunities through this program. These programs are helping the tribal women to improve the socio economic conditions and to accomplish the inclusive growth in India. TRICOR should provide immediate self-employment/loans to beneficiaries after the training selection process of the beneficiaries should be fast and need to be extended the training period time for more practice. Additional training should provide the TRICOR for upgrade the technological changes. It is high time to take the progress reports in post training period by visiting to the beneficiaries.

\section{References}

Bhukya, R. (2015). Empowerment of tribal women in India. Indian Journal of Research Paripex, 4(4), 4-5.

Chatterjee, P. (2014). Social and economic status of tribal women in India - The challenges and the road ahead. International Journal of Interdisciplinary and Multidisciplinary Studies 2(2), 55-60.

Das, G. (2012). Autonomy and decision making role of tribal women: A case study of Santoshpur village in Sundergargh district of Odisha [Dissertation]. Department of Humanities and Social Sciences, National Institute of Technology, Rourkela.

Dhanasree, K, Vijayabhinandana, B, \& Pradeepkumar, P. B. (2014). Socio-economic empowerment of tribal women in high altitude and tribal zone of Andhra Pradesh. International Journal of Innovative Research in Science, Engineering and Technology, 3(2), 9360-9368.

Lagachu, R. (2016). Education and women rights of missing tribe: A case study on Jengrai Panchayat (Majuli) of Jorhat District, Assam. International Journal of Humanities \& Social Science Studies, May, 261-267.

Naresh, G. (2014). Work participation of tribal women in India: A development perspective. IOSR Journal Of Humanities And Social Science, 19(12), 35-38. https://doi.org/10.9790/0837-191223538

Pallavi, S. K., \& Nagaraja, S. (2013). Economic status of tribal women: A case study. IJSR - International 
Penumala, V. K., \& Malyadri, P.

Journal Of Scientific Research, 2(1), 117-118.

Pandey, K. (2011). Socio-economic status of tribal women: A study of a transhumant Gaddi population of Bharmour, Himachal Pradesh, India. International Journal of Sociology and Anthropology, 3(6), 189-198.

Rao, D. P. (2013). Socioeconomic status of scheduled tribes. Global International Journal of Management, 1(1), 36-50.

Salehin, M. A. (2012). Reproductive health of tribal populations in India: A sustainability approach [Dissertation]. The University of Texas at Arlington.

Sharma, R. K., \& Rani, M. (2009). Contraceptive use among tribal women of central India: Experiences among DLHS-RCH-II survey. Research and Practice in Social Sciences, 5(1), 44-66.

TRICOR. (n.d.). TRICOR action plans from 2013-14 to 2015-16. Government of Telangana State, India. 